\title{
ERROR ANALYSIS ON ENGLISH WRITING SKILL FOR THE FIRST SEMESTER STUDENTS
}

\author{
Bejo Sutrisno \\ A Lecturer of STIBA-IEC Jakarta \\ bjs_sutrisno@yahoo.co.id
}

\begin{abstract}
The objective of this research is to find out the most and the least of typical errors on the first semester students' writing skill. Writing gives an important role to students in practicing their ability to express their ideas to readers. The students sometimes commit errors when they write and those errors can effect to the content of their writing, as the result, the readers will be confused or do not understand to the students' writing. This research using content analysis method. The writer interprets the data based on the errors on the students' writing. This research found that error analyzes of students' writing on word form is in the first rank (14,6\%) followed by word choice $(11,5 \%)$, Article and add a word $(9,5 \%)$, Omit a word, singular-plural, verb tense, and capitalization $(8,3 \%)$, Word order and Incomplete sentence $(6,2 \%)$ and the least error is on Meaning not clear, that is $(0 \%)$. This research has the implication that the lecturers should treat errors made by students as a part of learning process and it should be solved through remedial activity.
\end{abstract}

\section{Keywords: Error analysis, writing, content analysis}

\section{A. INTRODUCTION}

\section{Background}

As the foreign language, English is taught formally in schools in Indonesia started from Elementary school until University. English is also used as a target language in the classroom. There are four skills to be taught in English subject; Reading, Speaking, Listening and Writing. These four skills are taught integratedly. The language components (grammar, vocabulary, spelling and pronunciation) are not taught separately for the mastery of the language.

In the teaching and learning process, the role of English teachers is very important to motivate and encourage their students to gain success in learning 
language. Students' success is not only influenced by students' own factors, but also by other factors like teaching methods done by the teachers, or teachers' approach on how to make students study more effectively and obtain what they hope in learning the language. Therefore, the teachers have to entirely understand how to manage the limited time so that the greater result of teaching and learning process could be gained optimally.

Writing gives an important role to students in practicing their ability to express their ideas and to convey message to readers. Penny Ur (1996:163) says that the purpose of writing is the expression of ideas, the conveying of messages to readers, so the ideas themselves should arguably be seen as the most aspect of writing.

However, writing is often considered as the most difficult skill to learn and to teach. In connection to writing is difficult, Nunan (1989:36) says :

"It has been argued that learning to write fluently and expressively is the most difficult of the macro skills for all language users regardless of whether the language in question is a first, second or foreign language".

Whereas, Penny Ur (1986:163) says that one of our problems in teaching writing is to maintain a fair balance between content and form when defining our requirements and assessing.

There are some factors which make the students think that writing is the most difficult skill to learn. The difference in spelling, pronunciation, the grammatical system and the selection of vocabulary between English and Indonesian Language are some of the most important factors that make the students think that writing is difficult. Due to those problems, therefore, the students sometimes commit errors when they write in English writing. Those errors can effect to the content of their writing, as the result, the reader will be confused or do not understand to their writing. In other word, their message does not convey successfully to the readers.

Based on the problem above, the writer concerns to the importance of doing Error Analysis. Through Error Analysis, the common writing errors that the students make can be identified and they do not commit the same error again in the future. Therefore, Error Analysis in writing actually should always be done by the teacher more often. Ellis as quoted by Prof. Henry Guntur and Drs. Djago Tarigan (1990:68) says:

"Analisis kesalahan adalah suatu prosedur kerja yang biasa digunakan oleh para peneliti dan guru bahasa, yang meliputi pengumpulan sample, pengidentifikasian kesalahan, yang terdapat dalam sample, penjelasan kesalahan tersebut, pengklasifikasian kesalahan itu berdasarkan penyebabnya, serta pengevaluasian atau penilaian taraf keseriusan kesalahan itu. 


\section{The Objective}

Relating to the problem above the objective of the study is to find out the most typical errors which are made by the students in writing.

\section{Theoretical Framework}

\subsection{The Definition of Writing}

Understanding the definition of writing, many linguists have presented the definition of writing variously. Davies (2000:96) in his book "Success in English Teaching" says that writing is probably the linguistic skill that is least used by most people in their native language. Furthermore, Gould (1989: x-xi) states that:

"In short, writing is not private; it is always a form of social dialogue, a way of talking to someone. Writing is a discovery process, a way of finding out what you are thinking and what you want to say in particular situation."

Hart (1986:2) also gives more definition about writing, he says that writing is a process of building larger units from smaller ones. that is, the writer uses words to make sentences, sentences to make paragraphs, and paragraphs to make compositions-letters, reports, college themes. Whereas, Drs. Ano Karsono (1986:15) has his own definition about writing, he says:

"Mengarang adalah mengutarakan sesuatu dengan menggunakan bahasa secara tertulis."

From those definition of writing above, it can be inferred that writing is a language skill which is used to communicate indirectly with other people. Therefore, since the people are not physically present, we must write as clear and precise as possible. It means through writing we are able to shares ideas, arouse feelings, persuade and convince other people. The ability to write well is also an asset in most careers. The search for a job usually requires a letter of application and a resume. A poorly written letter of resume invites rejection (Hart, 1986:2).

\subsection{The Characteristic of Written Language}

There are quite a number of relevant differences between spoken and written language. Basic characteristics of written language maybe so different 
from their native language. H. Douglas Brown (2001: 303-305) states some characteristics of written language, they are as follows:

\section{1) Permanence}

Written language is permanent, and therefore the reader has an opportunity to return again and again. If necessary, to a word or phrase or sentence, or even a whole text.

\section{2) Processing time}

A corollary to the above is the processing time that the reader gains. In practice, except for the time factor itself, fast readers do not necessary have an advantage over slow readers.

\section{3) Distance}

The written word allows messages to be sent across two dimensions: physical distance and temporal distance. The pedagogical significance that was written in some other place at some other time with only the written words themselves as contextual clues.

\section{4) Orthography}

In writing we have graphemes-that's it! Yes, . Sometimes punctuation, pictures, or charts lend a helping hand. And, yes, a writer can describe the aforementioned phonological cues, as in, with loud, rasping grunts, punctuate by roars of pain, he slowly dragged himself our of the line of enemy fire.

\section{5) Complexity}

You might be tempered to say that writing is more complex than speech, but in reality, that would be difficult to demonstrate. Writing and speech represent different modes of complexity, and the most salient difference is in the nature of clauses. The shorter clauses are often a factor of the redundancy we build into speech (repeating subjects and verbs for clarity.

\section{6) Vocabulary}

It is true that written English typically utilizes a greater variey of lexical iems than spoken conversational English. In our everyday give and take with family, friends, and colleagues, vocabulary is limited. Because writing allows the writer more processing time, because of a desire to be precise in writing, and simply 
because of the formal conventions of writing, lower frequency words often appear.

\section{7) Formality}

Writing is quite frequently more formal than speech. what do we mean by that? Formality refers to prescribed forms that certain messages must adhere to. The reason that you can both recognize a menu and decide what to eat fairly quickly is that menus conform to certain conventions.

\subsection{General Purposes of Writing}

Although there are other writing purposes (for example, to entertain or to express oneself), Hart (1986:3) states that most of the writing will be to inform or to persuade.

1) To inform. Often your chief or only aim will be to provide information to your reader. Your assumption is that your reader knows little or nothing about the topic on which your wish to provide information.

2) To persuade. In persuasive writing, your aim is to convince your reader to adopt a particular position, to take a particular action, or to do both. If, in a letter to your local newspaper, you oppose plans to build a shopping mall near your neighborhood, your purpose is persuasion.

\subsection{Kinds of Writing}

Being familiar with some kinds of writing is required for students who want to be good at writing skill. Thomas Cooley (1992: 18-22) proposes several kinds of writing. They are as follows:

1) Writing to inform : Exposition

The main purpose of this kind of writing is to inform. Writing that aims to inform or explain in this way is often called "exposition", from the latin word exponere, meaning "to place out".

Expository prose attempts to place out, or arrange, the world before us for examination, like exhibits at a fair or gallery. It answers the journalistic questions that reporters traditionally put to the world: who, what, when, where, how, and why?

2) Writing to convince : Persuasion and Argumentation

A persuasive writing has the shape of logical argument is often called argumentation. The kind of persuasive writing may be said to appeal more to the head than to the heart. Instead of exhorting readers to action or belief in a cause, 
it seeks to convince them that a particular line of reasoning is valid and applicable.

3) Writing to create : Narration and Description

Narration is writing that tells a story. It focuses upon what happened. Our uncharitable discharge is largely narrative.

Good description can hope to do the same for people, places, and objects. Descriptive writing appeals directly to our physical senses. It tells us what the hospital room of test subject, No.331, for example, looks, feels, smells and even tastes like.

4) Writing to express the self : Journals, Autobiographies, Personal Essays

The underlying purpose of this kind of writing is psychological release, one of the motives behind diaries, journals, private letters, and some other autobiographical forms.

To a degree, all personal writing gives vent to the writer's inner self. It is thus "expressive" in the root sense of allowing the ego to "push out".

\subsection{The Objective of Teaching English}

The teaching of writing is a complicated and complex subject. To be good at writing requires the mastery of conceptual and judgmental elements, it also requires the mastery of grammatical and rhetorical devices. Penny Ur (1996: 163) states that one of our problems in teaching writing is to maintain a fair balance between content and form when defining our requirements and assessing.

Considering that writing is difficult, the students usually loose their interest in doing the activity of writing. The suitable and appropriate writing materials and activities for the students will help the teacher stimulate and encourage his/her students to be motivated in learning writing. The teaching of writing has the objective to get learners to acquire the activities and skills they need to produce a range of different kinds of written texts, as Penny Ur (1996: 162) says:

"The objective of the teaching of writing in a foreign language is to get learners to acquire the abilities and skills they need to produce a range of different kinds of written texts similar to those an educated person would be expected to be able to produce in their own language"

Based on the objective of the teaching and writing above, it can be seen clearly that students should have more activities in practicing writing in the class. The aim of the commonest type of writing practice is to consolidate the learning of functional or grammatical items. The other main type of writing practice is intended to develop higher level writing skills. That means the activity to do the writing tasks in intermediate academic writing (Davies, 2000:96-97). 


\subsection{Components of Writing}

In teaching of writing activities, a teacher is expected to be able to recognize the general components of writing; content, form, grammar, style and mechanics. Haris (1974:68-69) states the five general components of writing. He says:

"Although the writing process has been analyzed in many different ways, most teachers would probably agree in recognizing at least the following five general components:

1. Content: the substance of the writing the ideas expressed.

2. Form: the organization of the content.

3. Grammar: the employment of grammatical forms and syntactic patterns.

4. Style: the choice of structures and lexical items to give a particular tone or flavor to the writing.

5. Mechanics: the use of the graphic conventions of the language.

Meanwhile, David Nunan (1989:38)says:

"Successful writing then involves:

- mastering the mechanics of letter formation;

- mastering and obeying conventions of spelling and punctuation;

- using the grammatical system to convey one's intended meaning; to reflect given/ new information and topic/ comment structures;

- polishing and revising one's initial efforts;

- selecting an appropriate style for one's audience."

From those statements above, it can be seen that a good writing is the writing which involves the mastery of the mechanics, the letter formation, spelling and punctuation, the use of grammatical system, and the selection of the appropriate style for the readers.

\subsection{Writing Learning Activities}

Writing is considered as the teaching activity which spends most time in the classroom. Because of the limitation of the time in the classroom, the teacher often gives writing as the homework for the students. Frequently, writing is regarded as the status of homework. In relation to the writing learning activities, Harmer (1991:139) prints out: 
"It is often easier to provide opportunities for spoken communication in the classroom than it is for the written medium. Frequently writing is relegated to the status of homework. This is a pity since writing, especially communicative writing, can play a valuable part in the class."

From the statement above, it is clear that writing has little opportunity in the classroom. Good writing should have some basic skills, a good deal of practice and some specific training. Paul Davies (2000:96) states that good writing skills usually develop from extensive reading, some specific training, and a good deal of practice. Writing involves the following basic skills:

- $\quad$ hand writing or typing

- spelling

- constructing grammatical sentences

- punctuation

In addition to recognizing some basic skills, Penny Ur (1996: 163) says that students should also often do some writing activities in the classroom. Teachers of English can help students practice writing by giving some instructional for writing activities, such as:

1) The sentences in the following paragraph have been jumbled. Write them out in the correct order.

2) Finish the following sentences in a way that makes the underlined word clear. For example:

An expert is someone who

3) The following story is written in the present tense, rewrite it in the past.

4) We have come to an exciting point in the story. Write down what you think will happen next, and why.

5) For a survey on child education in this country: could please state your main criticisms of the way you were brought up?

\subsection{Assessment of Writing Skill}

Assessment involves the means of obtaining information about students' abilities, knowledge, understanding, attainment, or attitudes. An assignment in writing, for instance, will be helpful in assessing a student's ability in and understanding of the assigned activity. Sommer (1989) defines assessment as the process of finding out who the students are, what their abilities are, what they need to know, and how they perceive the learning will affect them. Assessment places the needs of the students at the center of the teacher's planning. 
They are some forms of assessment of classroom-based writing, they are as follows:

(a) Portfolio Assessment

Some new ideas in the teaching of English become quickly established in practice because they are so right, so timely, so useful. The portfolio in writing classes is a case in point.

A typical writing portfolio contains the student's total writing output to represent his or her overall performance, but it may also contain only a selection of works which the students has chosen for the teacher to evaluate. In other words, portfolios show a student's work form the beginning of the term to the end, giving both teacher and student a chance to asses how much the latter's writing has progressed.

(b) Protocol Analysis

A second, though somewhat complicated, means of assessing students writing is protocol analysis. Actually, protocol analysis, as well as the other non traditional forms of assessment, is a writing procedure that promotes the process approach to writing.

Protocol analysis is also known as the composing aloud protocol or a think aloud activity, which is the exact opposite of the fixed model used by traditional composition teachers.

Assessment of student writing can be done using this strategy, for through protocol analysis, a teacher can tell how students write, the strategies they use to generate ideas, how often they revise and edit their work, and whether their written work has improved.

(c) Learning Logs

learning logs help teachers see what their students are learning log, students write on the knowledge they have gained from studying in their writing classes, and from their own thinking. A teacher need not grade learning logs, but can assess how much a student has gained of benefited from the writing class.

(d) Journal Entries

Journal entries may be used as an informal means of assessment by the teacher because they are personal and intimate. The teacher can write short notes in response to students' thoughts.

(e) Dialogue Journals

another nontraditional form of assessment of writing is dialogue journals these are written conversations between teacher and student over a period of time, usually for duration of a course, on topics that are of special interest to them. Their goal is to "communicate in writing, to exchange ideas and information free of the concern for form and correctness so often imposed on developing writers" (Jones, 1991, p. 3, in Peyton \& Staton, 1991). 
Dialogue journals provide guidance to the learner in expressing ideas, thoughts, feeling, and emotions. Dialogue journal interaction leads trust between learner and teacher (Jack C. Richards and Willy A. Renandya, 2002:346-350).

\subsection{The Nature of Error Analysis}

In learning a foreign language, especially in writing English, making errors is common problem for the students, and they are not separated between learning foreign language and making errors. In practicing writing English, the learners will produce the utterance which are ungrammatical. Furthermore, in Indonesia where English is used as a foreign language, this condition is also often found. The cause of this is that the difference between the system of the learners' mother tongue-in this case Indonesian and English. The differences usually make students confused when they are asked to produce sentences in English. In accordance with the difficulty in learning a foreign language especially in writing, Nunan (1989:36) states that:

"It has been argued that learning to write fluently and expressively is the most difficult of the macroskills for all language users regardless of whether the language in question is a first, second or foreign language".

In this case, Brown (2001:170) states that it will be helpful to distinguish between error and mistake. An error is a noticeable deviation from the adult grammar of a native speaker, reflecting the interlanguage competence of the learner. Otherwise, a mistake refers to a performance error that is a random guess or a "slip," in that it is a failure to utilize a known system correctly. Whereas, Prof. Dr. Henry Guntur Tarigan and Drs. Djago Tarigan (1988:75-76) give the explanation about the difference phenomena between error and mistake. They state:

"Istilah kesalahan ("error") dan kekeliruan ("mistake") dalam pengajaran bahasa dibedakan yakni penyimpangan dalam pemakaian bahasa.

Kekeliruan ("mistake") umumnya disebabkan oleh faktor performansi. Keterbatasan dalam mengingat sesuatu atau kelupaan menyebabkan kekeliruan dalam melafalkan bunyi bahasa, kata, urutan kata, tekanan kata atau kalimat, dan sebagainya.

Sebaliknya, kesalahan disebabkan oleh faktor kompetensi. Artinya, siswa memang belum memahami system linguistik bahasa yang digunakannya. Kesalahan biasanya terjadi secara sistematis. Kesalahan itu dapat berlangsung lama apabila tidak diperbaiki. Perbaikan biasanya dilakukan oleh guru misalnya melalui pengajaran remedial, latihan, praktek dan sebagainya." 
It is clear that the role of English teacher is very important and essential in giving the response towards students errors in the relation to improving students' writing skill. By giving the appropriate response, students are expected to be motivated and the process of teaching and learning writing is also hopefully to be enjoyable for the students. In other words, students are supposed to be interested and enthusiastic in learning English, especially writing.

\subsection{Error Analysis}

Teachers of English should not let their students make errors longer and longer. They should give treatment or remedial to those errors right away. If the errors keep longer, the students may commit the same error if there are no English teachers point out the students' errors in writing English. As the result, it will be difficult for the teachers to reach the objective of teaching English. In this case the teacher can choose the error analysis as the alternative way to help students on learning English especially writing. Error analysis is a work procedure that usually used by researchers and teachers, consist of collecting sample, identifying errors, classifying errors and calculating errors. As Ellis cited in Prof. Dr. Henry Guntur Tarigan, et, al (1990:68) state that:

"Analisis kesalahan adalah suatu prosedur kerja yang biasa digunakan oleh para peneliti dan guru bahasa, yang meliputi pengumpulan sample, pengidentifikasian kesalahan, yang terdapat dalam sample, penjelasan kesalahan tersebut, pengklasifikasian kesalahan itu berdasarkan penyebabnya, serta pengevaluasian atau penilaian taraf keseriusan kesalahan itu."

Whereas, Brown (1987:171) states that error analysis is the fact that learners do make errors and that these errors can be observed, analyzed, and classified to reveal something of the system operating within the learner, led to a surge of study of learners' errors.

In addition, S.K Sharma (1988:76) also gives more definition and the objective of error analysis:

"Error Analysis is a process based on analysis of learners' errors with one clear objective: evolving a suitable and effective teaching-learning strategy and remedial measures necessary in certain clearly marked out areas of the foreign language." 


\subsection{The Objective of Error Analysis}

In accordance with the objective of error analysis which has been stated by K. Sharma above that one clear objective of error analysis is evolving a suitable and effective teaching-learning strategy and remedial measures necessary in certain clearly marked out areas of the foreign language. Whereas, Prof. Dr. Henry Guntur Tarigan and Djago Tarigan (1988:69) mention another objective of error analysis. They are as follows:

"Analisis kesalahan, antara lain bertujuan untuk:

(1) menentukan urutan penyajian butir-butir yang diajarkan dalam kelas dan buku teks, misalnya urutan mudah-sukar.

(2) Menentukan urutan jenjang relatif penekanan, penjelasan dan latihan berbagai butir bahan yang diajarkan.

(3) Merencanakan pelajaran dan pengajaran remedial

(4) Memilih butir-butir bagi pengujian kemahiran siswa (Sidhar, 1985:2212)"

\subsection{Error Analysis on Writing Skill}

How do English teacher give response to the result of students' writing in English? Most teachers cannot resist and cannot be patient to do the correction and evaluation to the students' written work whether it is in the form of a simple sentence, short paragraph, or composition, Jack C. Richards (2002:350-351) in his book 'Methodology in Language Teaching' prints out:

"How do language teachers respond to their students' written compositions? Most teachers cannot resist the temptation to correct all errors, both global and local, in their students' compositions. Generally, in the case of global errors (errors that impede communication), teachers substitute their own words, sentences, and even ideas for their students' errors so that these students lose ownership of their writings; they can barely recognize their own work this contributes to many students' dislike for writing. Responding to students writing, if done properly, may lead to students' improved written work and may make writing interesting, challenging, and enjoyable."

It is clear that the role of English teachers is very important and essential in giving the response towards students' errors in teaching and learning activities to improve students' writing skill. By giving the appropriate response, students will be motivated and the process of teaching and learning activities especially writing will be enjoyable for the students. In other words, students will be interested and enthusiastic in learning English, especially writing. 


\section{METHODOLOGY}

The population is the first grade students of a collage in East Jakarta. In this study the writer takes one class from the three classes as the sample which consists of 18 students. The research is held at STIBA-IEC Jakarta of academic year $2015-2016$. The method used in this paper is descriptive research method to describe and interpret the exact data based on the procedures of error analysis stated in chapter II.

\section{RESULT AND DISCUSSION}

\section{Result}

There are eighteen students as the sample of this research. Here, the writer took 5 samples as the representatives of eighteen samples of data analysis.

Sample 1

\begin{tabular}{|l|l|l|l|}
\hline No & \multicolumn{1}{|c|}{ Data } & Error Classification & \multicolumn{1}{|c|}{ Reconstruction } \\
\hline 1 & I am student. & Article & I am a student. \\
\hline 2 & I am old sixten & $\begin{array}{l}\text { Word order, add a } \\
\text { word, spelling }\end{array}$ & I am sixteen years old. \\
\hline 3 & $\begin{array}{l}\text { I live Lebak bulus V, Rt } \\
\text { o14/ Rw 004. }\end{array}$ & $\begin{array}{l}\text { Add a word, } \\
\text { capitalization }\end{array}$ & $\begin{array}{l}\text { I live in Lebak Bulus V, Rt } \\
\text { 014/ Rw 004. }\end{array}$ \\
\hline 4 & $\begin{array}{l}\text { after I school, I eating, } \\
\text { television. }\end{array}$ & $\begin{array}{l}\text { Capitalization, add a } \\
\text { word, omit a word, } \\
\text { word form }\end{array}$ & $\begin{array}{l}\text { After school I eat and watch } \\
\text { television. }\end{array}$ \\
\hline 5 & $\begin{array}{l}\text { Two brothers one isters. } \\
\text { Incomplete } \\
\text { sentence, singular- } \\
\text { plural }\end{array}$ & $\begin{array}{l}\text { I have two brothers and one } \\
\text { sister. }\end{array}$ \\
\hline 6 & $\begin{array}{l}\text { my brother is student a } \\
\text { student. }\end{array}$ & $\begin{array}{l}\text { Capitalization, omit a } \\
\text { word }\end{array}$ & My brother is a student. \\
\hline 7 & $\begin{array}{l}\text { I happy. } \\
8\end{array}$ & $\begin{array}{l}\text { Omit a word, add a } \\
\text { word, incomplete } \\
\text { sentence. }\end{array}$ & I am happy in my family. \\
\hline I help to father and & Omit a word & I help my father, my mother \\
\hline
\end{tabular}




\begin{tabular}{|l|l|l|l|}
\hline & mother and sisters. & & and my sisters. \\
\hline 9 & $\begin{array}{l}\text { my family stay at home } \\
\text { and watch TV my family } \\
\text { in holiday go to Puncak. }\end{array}$ & $\begin{array}{l}\text { Capitalization, word } \\
\text { order, add a word }\end{array}$ & $\begin{array}{l}\text { In a holiday, my family } \\
\text { stays at home and watch } \\
\text { TV and sometimes goes to } \\
\text { Puncak. }\end{array}$ \\
\hline
\end{tabular}

Sample 2

\begin{tabular}{|l|l|l|l|}
\hline No & \multicolumn{1}{|c|}{ Data } & Error Classification & \multicolumn{1}{|c|}{ Reconstruction } \\
\hline 1 & I am fiveteen years old. & Spelling & I am fifteen years old. \\
\hline 2 & $\begin{array}{l}\text { After school I watching } \\
\text { television. }\end{array}$ & Word form & $\begin{array}{l}\text { After school I watch } \\
\text { television. }\end{array}$ \\
\hline 3 & $\begin{array}{l}\text { My father is security and } \\
\text { my mother housework. }\end{array}$ & $\begin{array}{l}\text { Capitalization, } \\
\text { article, add a word }\end{array}$ & $\begin{array}{l}\text { My father is a security and } \\
\text { my mother is a housewife. }\end{array}$ \\
\hline 4 & $\begin{array}{l}\text { They is student and } \\
\text { housewife. }\end{array}$ & $\begin{array}{l}\text { Word choice, } \\
\text { singular-plural, } \\
\text { article }\end{array}$ & $\begin{array}{l}\text { My brothers are students } \\
\text { and my sister is a } \\
\text { housewife. }\end{array}$ \\
\hline 5 & I happy. & $\begin{array}{l}\text { Add a word, } \\
\text { incomplete sentence }\end{array}$ & I am happy in my family. \\
\hline 6 & $\begin{array}{l}\text { My family in holiday a } \\
\text { enjoying and watching } \\
\text { television. }\end{array}$ & $\begin{array}{l}\text { Word order, word } \\
\text { form, omit a word. }\end{array}$ & $\begin{array}{l}\text { In a holidy, my family } \\
\text { enjoys watching television. }\end{array}$ \\
\hline
\end{tabular}

Sample 3

\begin{tabular}{|l|l|l|l|}
\hline No & \multicolumn{1}{|c|}{ Data } & Error Classification & \multicolumn{1}{|c|}{ Reconstruction } \\
\hline 1 & $\begin{array}{l}\text { After going home from } \\
\text { school I usually have } \\
\text { lunch and after it I } \\
\text { sleep. }\end{array}$ & $\begin{array}{l}\text { Capitalization, word } \\
\text { choice }\end{array}$ & $\begin{array}{l}\text { After going home from } \\
\text { school I usually have lunch } \\
\text { and after that I sleep. }\end{array}$ \\
\hline 2 & $\begin{array}{l}\text { My father's job is } \\
\text { emmployee and my } \\
\text { mother is housewife. }\end{array}$ & Article, spelling & $\begin{array}{l}\text { My father's job is an } \\
\text { employee and my mother is } \\
\text { a housewife. }\end{array}$ \\
\hline 3 & $\begin{array}{l}\text { With study diligent to } \\
\text { express my love to my }\end{array}$ & $\begin{array}{l}\text { Word order, word } \\
\text { form, spelling }\end{array}$ & $\begin{array}{l}\text { To express my love to my } \\
\text { sister by loving them and }\end{array}$ \\
\hline
\end{tabular}




\begin{tabular}{|l|l|l|l|}
\hline & sister's by loving them. & & studying diligently. \\
\hline 4 & $\begin{array}{l}\text { every holiday we are } \\
\text { going to the mountaint. }\end{array}$ & $\begin{array}{l}\text { Capitalization, verb } \\
\text { tense, spelling }\end{array}$ & $\begin{array}{l}\text { Every holiday we go to the } \\
\text { mountain. }\end{array}$ \\
\hline
\end{tabular}

Sample 4

\begin{tabular}{|l|l|l|l|}
\hline No & \multicolumn{1}{|c|}{ Data } & Error Classification & \multicolumn{1}{|c|}{ Reconstruction } \\
\hline 1 & $\begin{array}{l}\text { After school I watching } \\
\text { television. }\end{array}$ & word form & $\begin{array}{l}\text { After school I watch } \\
\text { television. }\end{array}$ \\
\hline 2 & I happy in family. & Add a word & I am happy with my family. \\
\hline 3 & $\begin{array}{l}\text { I will help they with help } \\
\text { them. }\end{array}$ & $\begin{array}{l}\text { Meaning not clear, } \\
\text { word form }\end{array}$ & I will help them. \\
\hline 4 & $\begin{array}{l}\text { My family in holiday go } \\
\text { to recreation }\end{array}$ & $\begin{array}{l}\text { Word order, word } \\
\text { choice. }\end{array}$ & $\begin{array}{l}\text { In a holiday, my family goes } \\
\text { for recreation. }\end{array}$ \\
\hline
\end{tabular}

Sample 5

\begin{tabular}{|c|c|c|c|}
\hline No & Data & Error Classification & Reconstruction \\
\hline 1 & I am fifteen year old. & Singular-plural & I am fifteen years old \\
\hline 2 & After school I sleep & Capitalization & $\begin{array}{l}\text { After school I (usually) } \\
\text { sleep. }\end{array}$ \\
\hline 3 & $\begin{array}{l}\text { My father is trader and } \\
\text { my mother is housewife. }\end{array}$ & article & $\begin{array}{l}\text { My father is a trader and } \\
\text { my mother is a housewife }\end{array}$ \\
\hline 4 & $\begin{array}{l}\text { my first sister is height } \\
\text { school and my brother } \\
\text { is Junior school. }\end{array}$ & $\begin{array}{l}\text { Capitalization, omit a } \\
\text { word, add a word, } \\
\text { word choice }\end{array}$ & $\begin{array}{l}\text { My sister is in high school } \\
\text { and my brother is in Junior } \\
\text { high school }\end{array}$ \\
\hline 5 & I happy in our family. & $\begin{array}{l}\text { Add a word, word } \\
\text { choice }\end{array}$ & I am happy in my family. \\
\hline 6 & $\begin{array}{l}\text { I express love to my } \\
\text { parent to meek they } \\
\text { happy. }\end{array}$ & $\begin{array}{l}\text { Add a word, } \\
\text { singular-plural, word } \\
\text { choice, spelling. }\end{array}$ & $\begin{array}{l}\text { I express my love to my } \\
\text { parents by making them } \\
\text { happy. }\end{array}$ \\
\hline 7 & $\begin{array}{l}\text { I express love to my } \\
\text { brother and sister to } \\
\text { meek. }\end{array}$ & $\begin{array}{l}\text { Incomplete } \\
\text { sentence, spelling. }\end{array}$ & $\begin{array}{l}\text { I express my love to my } \\
\text { brother and my sister to } \\
\text { make them happy. }\end{array}$ \\
\hline
\end{tabular}


The finding of data analyzed can be seen at the table of recapitulation of students' error in writing below.

Table of Recapitulation on Students' Writing Errors

\begin{tabular}{|c|c|c|c|c|c|c|c|c|c|c|c|c|c|c|c|c|c|c|c|c|}
\hline \multirow{2}{*}{$\begin{array}{c}\text { Error } \\
\text { Classification }\end{array}$} & \multicolumn{18}{|c|}{ Students } & \multirow{2}{*}{ Total } & \multirow{2}{*}{$(\%)$} \\
\hline & 1 & 2 & 3 & 4 & 5 & 6 & 7 & 8 & 9 & 10 & 11 & 12 & 13 & 14 & 15 & 16 & 17 & 18 & & \\
\hline Singular-plural & 1 & - & 1 & - & 1 & 1 & - & 1 & - & - & 1 & - & - & 1 & 1 & - & - & - & 8 & 8.3 \\
\hline Word form & 1 & 1 & 1 & - & 1 & - & 1 & 1 & 1 & - & 1 & - & 1 & 1 & 1 & & 1 & 1 & 14 & 14.6 \\
\hline Word choice & 1 & 1 & 1 & - & 1 & 1 & 1 & - & 1 & - & - & 1 & - & 1 & - & 1 & & 1 & 11 & 11.5 \\
\hline Verb tense & 1 & - & - & 1 & - & - & - & 1 & - & - & - & 1 & - & - & 1 & - & - & 1 & 6 & 6.2 \\
\hline Add a word & 1 & - & 1 & - & 1 & - & 1 & - & 1 & 1 & - & - & 1 & - & 1 & - & 1 & - & 9 & 9.5 \\
\hline Omit a word & 1 & - & 1 & 1 & - & 1 & - & - & 1 & - & - & 1 & - & 1 & - & 1 & - & - & 8 & 8.3 \\
\hline Word order & 1 & - & 1 & - & - & 1 & - & - & - & 1 & - & - & 1 & - & - & - & 1 & - & 6 & 6.2 \\
\hline $\begin{array}{l}\text { Incomplete } \\
\text { sentence }\end{array}$ & - & 1 & - & 1 & - & - & 1 & - & - & - & 1 & - & - & 1 & - & - & - & 1 & 6 & 6.2 \\
\hline Capitalization & 1 & - & 1 & - & 1 & 1 & - & 1 & - & - & 1 & - & 1 & - & - & - & - & 1 & 8 & 8.3 \\
\hline Article & 1 & 1 & 1 & - & & 1 & - & 1 & - & - & 1 & - & - & 1 & 1 & - & 1 & - & 9 & 9.5 \\
\hline Spelling & 1 & 1 & & 1 & & 1 & 1 & 1 & & 1 & & & 1 & & 1 & & 1 & & 10 & 10.4 \\
\hline $\begin{array}{l}\text { Meaning not } \\
\text { clear }\end{array}$ & - & - & - & - & & - & - & - & - & - & - & - & & - & - & - & - & - & 0 & 0 \\
\hline Total & 10 & 5 & 8 & 4 & 5 & 7 & 5 & 6 & 4 & 3 & 5 & 3 & 5 & 6 & 6 & 2 & 5 & 5 & 96 & 100 \\
\hline
\end{tabular}

From the calculation of error analyzes of students' writing above, it can be seen that : word form is in the first rank (14,6\%) followed by word choice (11,5\%), Article and add a word (9,5\%), Omit a word, singular-plural, verb tense, and capitalization $(8,3 \%)$, Word order and Incomplete sentence $(6,2 \%)$ and the least error is on Meaning not clear, that is $(0 \%)$.

\section{Discussion}

1) Singular-plural

The word 'sister' must be in the form of plural 'sisters' because after the word 'two' must be plural form. 
(1) I have two sister and one brother

(wrong)

I have two sisters and one brother

(right)

2) Capitalization

The word 'Brother' must use small case letter ' $b$ ' not ' $B$ ' because is written in initial position.

(1) I have two sister and one Brother

(wrong)

I have two sisters and one brother

(right)

The word 'sosro' must use capital letter 'Sosro' because it is the name of conpany.

(2) ... my father gets many parcel from sosra.

(wrong)

... my father gets many parcel from Sosra.

(right)

\section{3) Word-Form}

The word 'sing' and 'read' must 'singing' and 'reading' because they are functioned as gerund (Verb-ing form functioned as Noun)

... and my hobbies are sing, read, jogging, shopping (wrong)

... and my hobbies are singing, reading, jogging, shopping

(right)

The word 'join' should also be 'joining' because it is functioned as gerund, it is after preposition 'in'.

(2) I am interested in join reading poem competition.

(wrong)

I am interested in joining reading poem competition

(right)

4) Omit a word

Phrase 'my mother' and 'my father' are not used anymore because there is the word 'my parents' which has the meaning 'both my father and my mother'.

My parents both my mother and my father work.

(wrong)

Both my parents work

5) Article

The use of article 'a second' should 'the second' because it is used for cardinal number.

$$
\begin{aligned}
& \text { I am a second in my family } \\
& \text { I am the second in my family }
\end{aligned}
$$


The word 'the doll' in this sentence is must be 'a doll' because the word 'doll' is not understood yet by the readers (indifinite article)

(2) I played the doll with my friends in my free time.

(wrong)

I played a doll with my friends in my free time.

(right)

6) Word choice

The use of preposition 'in' is the right preposition rather than 'from' because it has the meaning 'in a family'.

(1) I am the second from my family

(wrong)

I am the second in my family

The word 'important' is more suitable used than the word 'necessary' in the following sentence.

(2) English is very necessary

(wrong)

English is very important

(right)

7) Spelling

There is misspelling in the word 'aut's house"which must be 'aunt's house'.

(1) I lived in my aut's house.

(wrong)

I lived in my aunt's house

(right)

8) Verb tense,

Kata 'am' pada kalimat di bawah ini harusnya 'was' karena kalimat tersebut merupakan kalimat bentuk past tense.

(1) When I was a child, I am a very bad girl

(wrong)

When I was a child, I was a very bad girl

(right)

9) Incomplete sentence

The word 'in order to' must be followed by phrase and it can't stand alone at the end of a sentence.

(1) After I finish my study in here, I plan to go to another university to continue my study and also get a job in order to

(wrong)

After I finish my study in here, I plan to go to another university to continue my study in order to get a job.

(right) 
10) Add a word

In this sentence needs addition of word 'in'.

(1) When I was a senior high school

(wrong)

When I was in senior high school.

(right)

11) Word order

In this sentence besides it needs omission of phrase, it also needs to be in a good structure or word order.

(1) My parents both my mother and my father work.

(wrong)

Both my parents work

(right)

\section{CONCLUSIONS AND SUGGESTIONS}

\section{Conclusions}

After collecting the sample, identifying errors of the data, classifying the errors, and calculating the errors, the writer brings some conclusions relating to the objective of the research. The writer limits the three most typical errors of twelve types of errors on students' English writing skill.

The writer finds out that the three most typical errors on students' English writing skill at the first semester students of STIBA-IEC Jakarta are errors on word form (14,6\%), errors on word choice (11.5\%).

Whereas the two least typical errors are placed by errors on word order and incomplete sentence $(6,2 \%)$, and errors on meaning not clear $(0 \%)$

\section{Suggestions}

Based on the conclusions which have been stated above, the writer has some suggestions which may be useful and applicable for the lecturers of English Writing of the first semester students of STIBA-IEC.

1) Lecturers of English Writing should not let their students make errors more and more. They should give treatment or remedial to those errors right away.

2) The lecturer of the first semester of STIBA-IEC can make some groups of English study for their students and choose the better students to be the leader of each group so they can help their members who are still weak in writing. 
3) It is advisable for lecturers to treat errors made by learners of foreign language as a part of learning a language or as a positive aids to learning.

References

Brown, H. Douglas.2001. Teaching by Principles. Sans Francisco State University.

Brown, H. Douglas.1987. Principles of Lnguage Learning and Teaching, Prentice Hal. Inc.

Cooley, Thomas.1992. Guide to Writing. W W. Northon \& Company. New YorkLondon.

Davies, Paul.2000. Success in English Teaching. Oxford University Press.

Gould, Eric, et.al. 1989. The Act of Writing, Random House, New York.

Haris, David P. 1974. Testing English as the second language, Tata Mc. Graw-Hill.

Harmer, Jeremy.1991. The Practice of Language Teaching, Cambridge: Longman.

Hart, Andrew W. \& James A. Reinking.1986. Writing for Career Education Students. St. Martin's Press. Inc.

Karsono, Ano. 1986. Buku Materi Pokok 'Ketrampilan Menulis, Jakarta: Karunia, Universitas Terbuka.

Nunan, David. 1989, Designing Tasks for the communicative Classroom, Cambidge: Cambridge University Press

Nunan, David.1989. Designing Tasks for the communicative Classroom, Cambridge University Press.

Richards, Jack C. and Willy A. Renandya. 2002. Methodology in Language Teaching, Cambridge University Press.

Sharma, K. Error Analysis.1988. Why and How. Forum Anthology. Selected articles from the English Teaching Forum 1979 - 1983. Washington D.C. 20547.

Tarigan, Henry Guntur n \& Drs. Djago Tarigan.1990. Pengajaran Analisis Kesalahan Berbahasa, Bandung: Angkasa

Tarigan, Henry Guntur n \& Drs. Djago Tarigan.1988, Pengajaran Analisis Kesalahan Berbahasa, Bandung: Angkasa.

Ur, Penny.1996. A Course in Language Teaching (Ways of presenting the meaning of New items), Cambridge University Press. 